\title{
Spillovers from foreign firms through worker mobility: An empirical investigation ${ }^{*}$
}

\author{
Holger Görg and Eric Strobl \\ University of Nottingham and Université catholique de Louvain
}

\begin{abstract}
While there has been a large empirical literature on productivity spillovers from foreign to domestic firms this literature treats the channels through which these spillover effects work as a black box. This paper attempts to fill this gap in the literature. Our results suggest that firms which are run by owners that worked for multinationals in the same industry immediately prior to opening up their own firm have higher productivity growth than other domestic firms. This suggests that these entrepreneurs bring with them some of the knowledge accumulated in the multinational which can be usefully employed in the domestic firm. We do not find any positive effects on firm level productivity if the owner had experience in multinationals in other industries, or received training by multinationals.
\end{abstract}

Keywords: Foreign direct investment, spillovers, worker mobility, training

JEL classification: F21, F23, J61

October 2002

\footnotetext{
* Address for correspondence: Holger Görg, School of Economics, University of Nottingham, Nottingham NG7 2RD, UK. Tel. +44 115846 6393, fax +44 115951 4159, email holger.gorg@nottingham.ac.uk.

The authors are particularly grateful to Francis Teal and the CSAE at Oxford for the provision of and advice on the data. Thanks are also due to Laurie-Ann Agama, Salvador Barrios, Carl Davidson, Sourafel Girma, David Greenaway, Keith Head, Ray Riezman, Mark Schaffer, Beata Smarzynska and Dirk te Velde for helpful comments on an earlier draft. Holger Görg gratefully acknowledges financial support from the Leverhulme Trust (Programme Grant F114/BF).
} 


\section{Spillovers from foreign firms through worker mobility: An empirical investigation}

\section{Introduction}

Whereas early attitudes of host countries towards inward foreign direct investment (FDI) were rather sceptical this has changed notably over the last two or three decades. As a matter of fact, since the 1980s many countries have started to actively liberalise regulations on FDI. For example, a recent UN World Investment Report (UN 1999) shows that of 145 regulatory changes made by 60 countries, 94 percent created more favourable conditions for FDI. Many host countries are now actively encouraging the inflow of FDI by providing generous investment and/or tax incentives. While the expected potential benefits include employment creation, capital formation and export promotion, one of the most frequently given reason to attract FDI is the prospect of acquiring new technology which may spill over to the host country and allow host country firms to improve their performance.

More specifically, multinational companies are expected to have access to some sort of firm specific asset, manifesting itself as a superior knowledge base, production technology, or marketing and management technique (Markusen, 1995, Caves, 1996). By inviting multinationals into the country, host country governments expect that at least some of this firm specific asset will be transferred to domestic firms, thus enabling such firms to improve their performance in terms of productivity, skills, or export performance. This knowledge transfer can be either voluntary through technology transfer arrangements or involuntary through knowledge spillovers. 
A large literature has developed over the last two decades or so concerning itself with such knowledge, or productivity spillovers. ${ }^{1}$ Such spillovers are assumed to occur through three main channels. First, there are "demonstration effects", i.e., domestic firms learn through imitation from multinationals. Second, there is a "competition effect" where domestic firms face competition from more productive multinationals and, therefore, have to improve their own performance in order to be able to compete successfully. Third, spillovers may occur through movement of labour, whereby workers trained by or working in multinationals may decide to leave and join an existing or open up a new domestic firm, taking with them some or all of the firm specific knowledge of the multinational.

Many empirical studies have set out to measure the magnitude of such productivity spillovers for both developing and developed countries (e.g., Haddad and Harrison, 1993; Kokko, 1994; Aitken and Harrison, 1999; Girma et al., 2001; Barrios and Strobl, 2002) although these studies treat the mechanism by which the spillovers are supposed to occur as a "black box". As such they usually regress total factor or labour productivity of domestic firms on a number of covariates, including a measure of the extent of multinational presence in an industry. A positive and statistically significant coefficient on that variable is then interpreted to indicate the existence of positive productivity spillovers.

Perhaps the most important reason for the lack of studies on disentangling the channels through which spillovers work is the unavailability of detailed micro level data to do so. In this paper, we present a first attempt at measuring the third channel, namely the movement of workers from foreign to domestic firms. While this channel has been analysed in the recent theoretical literature (Fosfuri et al., 2001, Glass and Saggi, 2002), our

1 See Görg and Greenaway (2002) and Blomström and Kokko (1998) for concise reviews of that literature. Görg and Strobl (2001) look critically at the econometric specifications of the spillovers studies. 
paper is, to the best of our knowledge, the first to present a detailed analysis at the empirical level.

We have detailed firm level data for a sample of manufacturing firms in Ghana which allow us to tackle this issue. For our purposes we use information on the entrepreneur, i.e., owner or chairman of the firm. Specifically, we have data available on whether or not the entrepreneur worked for a foreign multinational before setting up his own firm and we can determine whether this experience was gained in the same or in other industries. Furthermore, the data show whether or not he received training by a multinational firm at any point during the sample period. Using these data, we investigate whether firms which have entrepreneurs with foreign training and/or experience have a productivity advantage compared to other firms. $^{2}$

Our econometric evidence indeed shows that firms whose entrepreneur worked in multinationals in the same industry are more productive than domestic firms. No such evidence is found for firms run by entrepreneurs who worked for multinationals in other industries. This may suggest that some of the multinationals' knowledge is industry specific and cannot be transferred to firms in other industries. Also, explicit training received by multinationals does not appear to affect the firm's performance. We discuss these results in more detail in the remainder of the paper, which is structured as follows. Section 2 briefly discusses the argument why we may expect spillovers through movements of workers. Section 3 presents the dataset while Section 4 contains the results of the econometric estimations. Section 5 summarises our findings and concludes.

\footnotetext{
${ }^{2}$ Note that we treat the decision of the entrepreneur to move from a foreign to a domestic firm as exogenous. We do not concern ourselves with this decision of the entrepreneur. The related literature argues that employees may decide to become entrepreneurs if the expected earnings are higher than the expected wage if remaining in employment. See, for example, Evans and Jovanovic (1989) and Evans and Leighton (1989).
} 


\section{Spillovers through worker mobility}

Spillovers can arise when workers receive training or accumulate experience working for multinationals, and then move to domestic firms or set up their own enterprise. When moving, they will take with them some of the knowledge they have acquired in the multinational which can be usefully employed by the domestic firm and help improve its performance. This channel for spillovers has recently been theoretically investigated by Fosfuri et al. (2001) who look at the conditions under which such spillovers occur. Moreover, Glass and Saggi (2002) also provide a formal representation of the movement of trained workers from multinationals to domestic firms as a channel for spillovers.

Empirical work in this area is, however, scarce. There is some evidence that multinationals are important providers of training activities in developing countries (ILO, 1981; Lindsey, 1986). Also, some studies found that in a comparison of domestic firms and multinationals, the latter provide more training than the former. Gershenberg (1987) provides evidence to that extent from a survey of 72 managers in manufacturing firms in Kenya. ${ }^{3}$ He also finds some evidence for movements of managers from multinationals to domestic firms. ${ }^{4}$ Djankov and Hoekman (1999) analyse enterprise level panel data for the Czech Republic. In their summary statistics they show that multinationals provide higher levels of training than domestic firms. Sousa (2001) appears to provide the most comprehensive analysis of training activities of multinationals. Using detailed data on workplaces in the UK he finds that multinationals are more likely to provide training, and

3 This finding is only true in a comparison of multinationals and purely domestic private firms. Multinationals do not appear to provide more training than joint ventures or publicly owned Kenyan companies. 
also provide higher intensities of training than domestic firms, controlling for a number of workplace and sector specific characteristics. Using a matched firm and worker level dataset for Ghanaian manufacturing firms, Görg, Strobl and Walsh (2002) find that workers who work for and receive training in foreign firms experience more rapid wage growth than workers being trained in domestic firms. This is consistent with their theoretical model which shows that training provided by foreign firms is more productivity than that of domestic firms and, hence, workers trained in foreign firms have steeper wage profiles.

The aforementioned studies show for a number of countries that the potential for spillovers through the movement of highly trained and experienced workers from multinationals to domestic firms exist. However, there is to the best of our knowledge no study to date that attempts to determine whether the domestic firms that receive the new workers actually benefit from spillovers. ${ }^{5}$ This is arguably at least partially due to the unavailability of detailed data at the micro level.

\section{Description of the data}

In an ideal world, one would like to have data on the history of all workers in firms to be able to trace back whether they have had any work experience, or have been trained by multinational companies before joining the current firm. Using such data one would then be able to determine whether employing those workers leads to the firm being more technology intensive, using better technology and, ultimately, being more efficient and

\footnotetext{
${ }^{4}$ Pack (2001) similarly points out that there is evidence for Taiwan that managers from multinationals leave to set up their own business.

${ }^{5}$ There are some empirical studies that show that inward FDI increases wages paid by domestic firms (e.g, Aitken et al, 1996, Girma et al., 2001, Sjöholm and Lipsey, 2001). These studies may be interpreted as providing some indirect evidence for spillovers through labour mobility, leading to higher wages in domestic
} 
productive. While we do not have such detailed data on all workers in firm, we have data available on characteristics of the owner/chairman of a firm which allows us to investigate whether a domestic firm benefits if its entrepreneur came from a foreign firm.

The data used in this paper are drawn from the Regional Programme for Enterprise Development (RPED) dataset for Ghanaian manufacturing firms. The data consist of seven waves of an annual sample of Ghanaian manufacturing firms in the Food, Textiles and Garments, Wood, and Metal sectors, covering the years 1991-1997.,7, The dataset includes, amongst other things, data on the level of output, total expenditures on wages, the replacement value of the capital stock, the level of value added, and the level of employment. More importantly, the data collection entails an intricate questionnaire on the background of the owner, or, in the case of a corporation, the chairman of the firm. ${ }^{8}$ Specifically, one is able to identify whether the owner/chairman has received any explicit training by foreign firms in the past, whether their immediate previous experience was working with a foreign firm within the same industry as the industry of their current firm or in some other industry, and whether they have had any previous same industry experience in general. ${ }^{9}$ For the purposes here we are interested in investigating whether training and/or experience in a foreign firm by the owner/chairman affects firm level productivity growth, and create zero-one type dummy variables to indicate such.

\footnotetext{
firms. Our paper however attempts to provide some direct evidence on spillovers through worker movements.

${ }^{6}$ These sectors together comprise about 70 per cent of total manufacturing employment in Ghana.

${ }^{7}$ The initial sample of 200 firms was drawn from the 1987 Ghana Census of Manufacturing Activities, stratified by size, sector and location. It should be noted that in the sampling, large firms were oversampled. When firms closed down over the period they were replaced with firms in the same size, sector and location category.

${ }^{8}$ These data are not collected for foreign owned firms and public enterprises.

${ }^{9}$ These questions are re-asked if the firm changes ownership/chairmanship.
} 
Given that these are our main variables of interest they deserve some more discussion. In particular, it is important to point out that this group with foreign working and/or training experience will consist of any of the following three types: (1) persons who worked in a foreign firm immediately prior to their present occupation, (2) persons who worked for a foreign firm immediately prior to their present occupation and were explicitly trained by a foreign firm that may be either their immediately prior employer or some other previous foreign employer, (3) persons that were explicitly trained by a foreign firm but may have never worked for such, and, (4) persons that were explicitly trained by a foreign firm and have worked for a foreign firm (possibly although not necessarily the same firm) although not immediately prior to their current employment as entrepreneur/chairman. Given that the information on actual employment by a foreign employer only pertains to the experience immediately prior to becoming owner/chairman of the firm questioned, we are unable to identify those that were never explicitly trained but may have worked for a foreign firm, although not immediately prior to becoming the owner/chairman of their current firm. At any rate, out of the 204 domestic manufacturing firms included in our sample, the owners of 13 firms have immediate prior experience working in foreign firms in the same industry, 9 have immediate prior experience working with foreign firms in a different industries, and 14 received training provided by foreign firms.

Finally, the RPED data also includes information on the years of schooling of the owner/chairman. We explicitly use this variable to proxy for the level of human capital, excluding foreign training and experience, of the individual in question. ${ }^{10}$

\footnotetext{
${ }^{10}$ These are calculated in years. In some waves one has information on the age at which the individual left school and what qualification achieved, whereas in others on information on the former is available. Where possible we use information on both of these to construct years of schooling.
} 
Some summary statistics for our data for firms by ownership with and without foreign experience/training are given in Table 1. We calculate and compare a number of measures of firm performance, namely total factor productivity $(t f p),{ }^{11}$ output per worker $(q / l)$, value added per worker $(\mathrm{vad} / \mathrm{l})$, output $(q)$, value added $(v)$, capital and material inputs per worker $(k / l, m / l)$, average wage per employee $(w)$ and total employment $(l)$. All variables are expressed in logs. ${ }^{12}$

\section{[Table 1 here]}

As can be seen, firms owned or run by those with experience and/or training from foreign firms display on average greater labour productivity in terms of both measures of labour productivity, namely output per worker and value added per worker. These differences are statistically significant at the 1 per cent level. Also, they are significantly larger, in terms of output, value added or employment. Furthermore, these firms are more intensive in both capital and labour usage. The summary statistics do not indicate that they have higher TFP, however. Also, we find that firms run by owners without such experience or training pay higher wages, although this difference is only statistically significant at the 10 per cent level.

These figures may give some preliminary evidence supportive of the idea that there are spillovers from the movement of managers from multinationals to domestic firms, as firms run by owners who had such experience seem to have higher productivity, at least in terms of labour productivity. These figures are, of course, averages over fairly heterogeneous firms and the summary statistics may be confounding the effects of different sector, firm or owner characteristics. We turn therefore to an econometric analysis in order

\footnotetext{
${ }^{11}$ See the appendix for a description of how TFP was calculated.

${ }^{12}$ Nominal values are deflated using sectoral output price deflators.
} 
to disentangle the effect of foreign experience/training from other variables impacting on firm productivity.

\section{Econometric Analysis}

In order to test more properly for the existence of spillovers through worker mobility we estimate a set of different specifications of production functions in order to determine the effect of entrepreneurs' characteristics on firm level productivity. The basic specification of the empirical models is as follows

$$
\mathrm{dy}_{\mathrm{it}}=\beta_{0}+\beta_{1} \mathrm{y}_{\mathrm{it}-1}+\beta_{2} \mathrm{FT}_{\mathrm{it}}+\beta_{3} \mathrm{FE}_{\mathrm{ij}}+\beta_{4} \mathrm{FE}_{\mathrm{is}}+\beta_{5} \mathrm{CO}_{\mathrm{it}}+\beta_{6} \mathrm{CF}_{\mathrm{it}}+\beta_{5} \mathrm{D}_{\mathrm{j}}+\beta_{6} \mathrm{~T}_{\mathrm{t}}+\mathrm{e}_{\mathrm{it}}
$$

where $d y$ is the growth rate (in log differences) of the productivity measure $y$ for firm $i, y_{i t-1}$ is the lagged $\log$ level of $y . \quad C O$ is a vector including characteristics of the owner, namely, years of schooling and a dummy equal to one if the owner had any experience in the industry prior to founding or acquiring the current firm. $C F$ is a vector of firm characteristics depending on the specification of the productivity measure. $D$ and $T$ are full sets of sector and time dummy variables respectively and $e_{i t}$ is the remaining white noise error term.

The other three variables are dummy variables included to capture any spillovers from work experience or training received by multinationals. $F T_{i}$ is equal to one if the owner received training by a multinational. $F E_{i j}$ is a dummy equal to one if the owner of the firm had gained experience working for a multinational within the same industry $j$ prior 
to starting in the present firm, while $F E_{i s}$ is equal to one if previous experience was gained in a multinational in a different industry $s \neq j$. If all or part of the knowledge accumulated by workers is industry specific we would expect that experience gained in multinationals in the same industry would allow the entrepreneur to improve the performance of the domestic firm, while this effect would be less if experience were gained outside the industry.

We estimate a number of specifications of the productivity equation. Firstly, we use labour productivity, measured as either output per worker or value added per worker. While this measure has been commonly used in the literature on spillovers from foreign direct investment (e.g., Kokko, 1994; Barrios and Strobl, 2002) it captures only one aspect of productivity improvements. Spillovers may not only affect labour productivity but may also change the input mix and capital utilisation, therefore impacting on total factor productivity (TFP). Hence, we include three specifications estimating the determinants of TFP, two of which are based on estimating augmented production functions (as, for example, in Aitken and Harrison, 1999 and Haddad and Harrison, 1993) where the variables $F T_{i}, F E_{i j}$ and $F E_{i s}$ are included in the production function and are assumed to increase output or value added. The third specification is based on the estimate of TFP as the dependent variable, as described in the appendix.

Table 2 presents the results of estimating these different specifications of equation (1). The labour productivity and augmented production function estimations are based on first-differenced production functions. This allows us to purge any firm specific fixed effects in levels which may bias the result in levels if not properly dealt with. The economic justification for this approach is that we are not interested in whether firms run 
by owners with foreign training or experience have higher levels of productivity per se, but whether they have higher productivity growth. In other words, we do not concern ourselves with looking at the intercept shift due to spillovers, but we are interested in changes in the slope of the productivity function. Hence, we also look at TFP growth as dependent variable in column (5). Note that in the first set of estimations in Table 2 we do not control for any characteristics of the owner apart from the foreign training and experience variables.

[Table 2 here]

We find that experience in foreign firms in the same industry has a consistently positive effect on firm level productivity in all specifications. However, the coefficients on this variable are statistically insignificant in all cases. There is also no statistically significant evidence that foreign training received by the owner improves productivity. However, we find that the results obtained for experience accumulated in multinationals operating in a different industry are quite different. The coefficients on the dummy variable are negative for all productivity measures and statistically significant in three out of five cases. We will return to a possible explanation for this results below.

Before interpreting the results we need to address a number of possible caveats. A first obvious criticism to address at these first results is that foreign firms may be more likely to hire or provide training to more skilled workers as these workers already have better and more human capital. In that case, our foreign experience / training variables would be only measuring that the entrepreneur is of higher ability. In other words, while foreign experience or training may seem to increase productivity, this may only be due to the owners being better educated and/or more able a priori. Secondly, one may argue that 
the foreign experience variable in this first specification only picks up the effect of experience gained in the industry per se but does not represent an effect particular to experience gained in foreign firms. Thirdly, it may be the case that highly productive firms attract entrepreneurs that have gained experience in multinationals as they provide an attractive environment in which to work for the new entrepreneur. In that case the spillovers dummies would, of course, be endogenous.

Let us focus on the first two issues first. In order to take these points into account we re-estimated equation (1) now including two additional measures of the owner's ability. These are years of schooling of the entrepreneur and a dummy equal to one if he/she has any previous experience in the same industry. We also interact the schooling variable with the three foreign experience / training variables in order to capture the effect that more skilled employees may benefit differently from foreign experience / training than less skilled individuals.

The results of these estimations are reported in Table 3. The years of schooling variable shows consistently positive coefficients (statistically significant in two cases) which indeed suggests that more able individuals run more productive firms. Specifically, for columns (2) and (4) the results suggest that each additional year of schooling adds around 0.03 percentage points to productivity growth. Previous experience in the industry is in most cases negative but always statistically insignificant, however.

The inclusion of these two variables plus the interaction terms leads to some interesting changes in the significance of the spillovers variables. For within industry experience we now find a consistently positive and statistically significant coefficient in all cases, suggesting that owners who gained experience in multinationals in the same industry 
indeed run more productive firms. This, thus, provides evidence supportive of the idea that there are spillovers through worker movements, where the domestic entrepreneurs bring with them knowledge accumulated in the multinationals which can be usefully applied in the domestic firm. The consistently negative coefficient on the interaction term also suggests that the least skilled entrepreneurs can gain more from having experience in multinationals and thus that prior human capital and training received by foreign firms are not necessarily complements. Their individual human capital may benefit most from additional learning in multinationals compared to well educated domestic entrepreneurs who may gain only little additional knowledge.

There is also still evidence that gaining experience in multinationals outside the own industry has a negative effect on productivity. Again there is, however, evidence that this effect is lower the more skilled the entrepreneur. The coefficients on training provided by multinationals are still statistically insignificant in all cases, suggesting that training does not appear to be an important channel for spillovers.

\section{[Table 3 here]}

Of course, inferring causality from these results may still be difficult if, as pointed out above, our results pick up the fact that highly productive domestic plants attract entrepreneurs who gained experience in foreign firms. This criticism would not apply if these domestic firms were established by the owners, of course, and did not have a history of existence before the owner joined. Fortunately, from our dataset we can determine whether an owner established a firm himself and whether the business has been run by the owners family. Focusing on these two groups of firms should allow us to avoid the possible bias arising from productive firms attracting experienced high ability owners. 
Table 4, therefore, presents results of estimating the production functions using data only for firms if they were founded by the current owner or if they were run by the owners family before he took over ownership. Reassuringly, the results remain very similar to the results presented in Table 3 in terms of magnitude and statistical significance.

\section{[Table 4 here]}

Taken together, these results suggest that domestic firms which are run by entrepreneurs who gained experience working for multinationals in the same industry before running their own firms, show higher productivity growth than other firms. This may be interpreted as a sign that the entrepreneurs bring with them some of the knowledge accumulated in the multinational which can be usefully employed in the new domestic firm. Our finding that there is a negative effect if the entrepreneur gained his experience in multinationals in a different industry suggests that the knowledge obtained in multinationals is largely industry specific and can therefore not be easily transferred to businesses in different industries. It appears that, at least in the shortrun, these entrepreneurs run firms less productive than the average domestic firms perhaps due to their having to spend time building up or improving their industry specific knowledge and/or because the skills acquired in foreign firms may be even more industry specific than those acquired in domestic firms.

While these results concerning experience gained in foreign firms provide some evidence to the suggestion that there are spillovers from worker mobility, there is no evidence to suggest that firms also benefit if their owners receive training in multinationals. As the training variable only captures explicit training provided by multinationals it may, however, be the case that we are thus not able to measure adequately other types of more 
informal acquisitions of human capital and/or that explicit training only constitutes a small proportion of total human capital acquired in a foreign owned firm.

\section{Conclusions}

While there has been a large empirical literature on productivity spillovers from foreign to domestic firms this literature treats the channels through which these spillover effects work as a black box. Some theoretical work has recently stressed the importance of movement of workers from foreign to domestic firms as a channel for spillovers. To the best of our knowledge, however, there is to date no empirical study which investigates this issue in detail. We attempt to fill this gap in the literature with this paper.

While our results focus only on one possible mechanism for spillovers through worker movements, namely, the movement of the owner/chairman of the firm, they suggest that firms which are run by owners that worked for multinationals in the same industry immediately prior to opening up their own firm have higher productivity growth than other

firms. This implies that these entrepreneurs bring with them some of the knowledge accumulated in the multinational which can be usefully employed in the new domestic firm. We do not find any positive effects on firm performance if the owner had experience in multinationals in other industries, or received training by multinationals.

These results suggest that domestic firms can benefit from multinationals operating in the same industry. Thus, our findings provide a counterbalance to Kugler (2000) who argues and provides evidence for Colombia that domestic firms only benefit from interindustry but not from intra-industry spillovers from multinationals. At least in the case of spillovers from worker movements domestic firms are likely to benefit more from 
multinationals in the same industry as at least some of the knowledge transferred is likely to be industry specific. 


\section{References}

Aitken, B.J. and A.E. Harrison (1999), "Do Domestic Firms Benefit from Direct Foreign Investment? Evidence from Venezuela", American Economic Review, Vol. 89, pp. 605-618.

Aitken, B., A. Harrison and R.E. Lipsey (1996), "Wages and foreign ownership: a comparative study of Mexico, Venezuela, and the United States", Journal of International Economics, Vol. 40, pp. 345-371.

Baltagi, B.H. and J.M. Griffin (1997), "Pooled estimators versus their heterogeneous counterparts in the context of the dynamic demand for gasoline", Journal of Econometrics, Vol. 77, pp. 303-327.

Barrios, S. and E. Strobl (2002), "Foreign Direct Investment and Productivity Spillovers: Evidence from the Spanish Experience", Weltwirtschaftliches Archiv, forthcoming.

Blomström, M. and A. Kokko (1998), "Multinational Corporations and Spillovers", Journal of Economic Surveys, Vol. 12, pp. 247-277.

Caves, R.E. (1996), Multinational Enterprise and Economic Analysis. Cambridge: Cambridge University Press.

Djankov, S. and B. Hoekman (1999), "Foreign investment and productivity growth in Czech enterprises", World Bank Economic Review, Vol. 14, pp. 49-64.

Evans, D.S. and B. Jovanovic (1989), “An estimated model of entrepreneurial choice under liquidity constraints”, Journal of Political Economy, Vol. 97, pp. 808-827.

Evans, D.S. and L.S. Leighton (1989), "Some empirical aspects of entrepreneurship", American Economic Review, Vol. 79, pp. 519-535.

Fosfuri, A.; M. Motta and T. Rønde (2001), "Foreign Direct Invesment and Spillovers Through Workers' Mobility", Journal of International Economics, Vol. 53, pp. 205-222.

Gershenberg, I. (1987), "The training and spread of managerial know-how: A comparative analysis of multinational and other firms in Kenya", World Development, Vol. 15, pp. 931939.

Girma, S., D. Greenaway and K. Wakelin (2001), "Who benefits from Foreign Direct Investment in the UK?", Scottish Journal of Political Economy, Vol. 48, pp. 119-133.

Glass, A.J. and K. Saggi (2002), "Multinational firms and technology transfer", Scandinavian Journal of Economics, Vol. 104, pp. 495-513.

Görg, H. and D. Greenaway (2002), "Much ado about nothing? Do domestic firms really benefit from foreign direct investment?", CEPR Discussion Paper DP3485.

Görg, H. and E. Strobl (2001), "Multinational Companies and Productivity Spillovers: A Meta-analysis”, Economic Journal, Vol. 111, pp. F723-F739.

Görg, H., E. Strobl and F. Walsh (2002), "Why do foreign firms pay more? The role of onthe-job training", GEP Research Paper 02/14, University of Nottingham. 
Haddad, M. and A. Harrison (1993), "Are there Positive Spillovers from Direct Foreign Investment? Evidence from Panel Data for Morocco", Journal of Development Economics, Vol. 42, pp. 51-74.

ILO (1981), Multinationals 'training practices and developments, Geneva: International Labour Office.

Kokko, A. (1994), "Technology, Market Characteristics, and Spillovers", Journal of Development Economics, Vol. 43, pp. 279-293.

Kugler, M. (2000), "The Diffusion of Externalities from Foreign Direct Investment: Theory ahead of Measurement", Discussion Paper 0023, University of Southampton.

Lindsey, C.W. (1986), "Transfer of technology to the ASEAN region by US transnational corporations“, ASEAN Economic Bulletin, Vol. 3, pp. 225-247.

Lipsey, R.E. and F. Sjöholm (2001), "Foreign Direct Investment and Wages in Indonesian Manufacturing", NBER Working Paper 8299.

Markusen, J.R. (1995), "The Boundaries of Multinational Enterprises and the Theory of International Trade", Journal of Economic Perspectives. Vol. 9. pp. 169-189.

Pack, H. (2001), "The Role of Foreign Technology Acquisition in Taiwanese Growth", Industrial and Corporate Change, Vol. 10, pp. 713-734.

Pesaran, M.H. and R. Smith (1995), "Estimating long-run relationship from dynamic heterogeneous panels", Journal of Econometrics, Vol. 68, pp. 79-112.

Sousa, N. (2001), "Multinationals and technology transfer through labour training", mimeo, University of Nottingham (presented at CEPR Workshop on "Labour market effects of European foreign investments", Dublin, July 2001).

UN (1999), World Investment Report 1999, Geneva: United Nations. 


\section{Appendix: TFP Calculation}

Using log values, we write the production function as $y_{i t} \equiv f\left(l_{i t}, k_{i t}, m_{i t}, T F P_{i t}\right)$, where $y$ is output and there are three factors of production, labour $(l)$, materials or cost of goods sold $(m)$ and capital stock $(k)$. For estimation purposes we employ a first-order Taylor approximation and write the production function as

$$
y_{i t}=\beta_{0}+\beta_{s} l_{i t}+\beta_{k} k_{i t}+\beta_{m} m_{i t}+T F P_{i t}
$$

TFP is assumed to follow the following AR(1) process:

$$
T F P_{i t}=\rho T F P_{i t-1}+\delta D_{t}+f_{i}+v_{i t}
$$

where $D$ is a common year-specific shock, $f$ is a time-invariant firm specific effect and $v$ a random error term. Note that we do not simply model productivity as a fixed effect, as that would imply that TFP differences are fixed, and there is no role for technology diffusion (convergence).

Recently the fundamental assumption of pooling individual times series data has been questioned. Pesaran and Smith (1995) demonstrate that standard GMM estimators of dynamic panel models lead to invalid inference if the response parameters are characterised by heterogeneity. They argue that one is better off averaging parameters from individual time series regressions. This is not feasible here since the individual firm's time series data is not of adequate length. However, we take some comfort from a recent comparative study by Baltagi and Griffin (1997) which concludes that efficiency gains from pooling are likely to more than offset the biases due to individual heterogeneity. Baltagi and Griffin (1997) especially point out the desirable properties of the GLS-AR(1) estimator, and we use this estimator to obtain estimates of the factor elasticities, and derive TFP as a residual term. 
Table 1:

Summary Statistics by Ownership with and without Foreign Training/Experience

\begin{tabular}{lll}
\hline & With & Without \\
\hline $\log (\mathbf{t f p})$ & 0.018 & 0.027 \\
$\log (\mathbf{q} / \mathbf{l})$ & 9.212 & $8.617^{* *}$ \\
$\log (\mathbf{v a d} / \mathbf{l})$ & 7.928 & $7.344^{* *}$ \\
$\log (\mathbf{q})$ & 13.064 & $11.501^{* *}$ \\
$\log (\mathbf{v a d})$ & 11.770 & $10.225^{* *}$ \\
$\log (\mathbf{k} / \mathbf{l})$ & 9.309 & $8.172^{* *}$ \\
$\log (\mathbf{m} / \mathbf{l})$ & 8.516 & $7.985^{* *}$ \\
$\log (\mathbf{w})$ & 1.629 & $1.938^{*}$ \\
$\log (\mathbf{l})$ & 3.871 & $2.871^{* *}$ \\
\hline
\end{tabular}

difference statistically significant at $+10 \% ; *$ significant at $5 \%$; * significant at $1 \%$

Table 2:

Basic regression results, year-on-year growth rates

\begin{tabular}{llllll}
\hline & $(1)$ & $(2)$ & $(3)$ & $(4)$ & $(5)$ \\
\hline & $\mathrm{d} \ln (\mathrm{q} / \mathrm{l})$ & $\mathrm{d} \ln (\mathrm{vad} / \mathrm{l})$ & $\mathrm{d} \ln (\mathrm{q})$ & $\mathrm{d} \ln (\mathrm{vad})$ & $\mathrm{d} \ln (\mathrm{tfp})$ \\
$\mathrm{y}_{\mathrm{t}-1}$ & -0.034 & -0.233 & -0.019 & -0.147 & -0.628 \\
& $(0.011)^{* *}$ & $(0.033)^{* *}$ & $(0.009)^{*}$ & $(0.026)^{* *}$ & $(0.060)^{* *}$ \\
$\mathrm{FT}_{\mathrm{i}}$ & -0.064 & -0.120 & -0.055 & -0.076 & 0.008 \\
& $(0.124)$ & $(0.288)$ & $(0.125)$ & $(0.293)$ & $(0.116)$ \\
$\mathrm{FE}_{\mathrm{ij}}$ & 0.085 & 0.187 & 0.077 & 0.145 & 0.065 \\
& $(0.072)$ & $(0.238)$ & $(0.070)$ & $(0.223)$ & $(0.075)$ \\
$\mathrm{FE}_{\mathrm{is}}$ & -0.015 & -0.650 & -0.031 & -0.736 & -0.473 \\
& $(0.115)$ & $(0.190)^{* *}$ & $(0.122)$ & $(0.218)^{* *}$ & $(0.149)^{* *}$ \\
$\mathrm{~d} \ln (\mathrm{k} / \mathrm{l})$ & -0.008 & 0.160 & & & \\
& $(0.027)$ & $(0.050)^{* *}$ & & & \\
$\mathrm{~d} \ln (\mathrm{m} / \mathrm{l})$ & 0.758 & & & & \\
& $(0.025)^{* *}$ & & & & \\
$\mathrm{~d} \ln (\mathrm{l})$ & -0.120 & -0.352 & 0.113 & 0.384 & \\
& $(0.056)^{*}$ & $(0.159)^{*}$ & $(0.044)^{*}$ & $(0.154)^{*}$ & \\
$\mathrm{~d} \ln (\mathrm{k})$ & & & -0.008 & 0.167 & \\
& & & $(0.027)$ & $(0.053)^{* *}$ & \\
$\mathrm{~d} \ln (\mathrm{m})$ & & & 0.762 & & \\
& & & $(0.025)^{* *}$ & & -0.010 \\
$\ln (\mathrm{l})$ & & & & & $(0.014)$ \\
& & & & & 0.003 \\
Constant & -0.045 & 2.113 & -0.109 & 1.969 & $(0.078)$ \\
& $(0.144)$ & $(0.429)^{* *}$ & $(0.153)$ & $(0.453)^{* *}$ & 580 \\
Observations & 580 & 585 & 580 & 585 & 0.40 \\
$\mathrm{R}$-squared & 0.89 & 0.30 & 0.89 & 0.28 & \\
\hline
\end{tabular}

Robust standard errors in parentheses

+ statistically significant at $10 \%$; * significant at 5\%; ** significant at $1 \%$

Regressions include sectoral and time dummies 
Table 3:

Alternative regression results including owner's ability

\begin{tabular}{|c|c|c|c|c|c|}
\hline & (1) & (2) & (3) & (4) & (5) \\
\hline & $\mathrm{dln}(\mathrm{q} / \mathrm{l})$ & $\mathrm{d} \ln (\mathrm{vad} / \mathrm{l})$ & $\operatorname{dln}(q)$ & $\mathrm{d} \ln (\mathrm{vad})$ & $\mathrm{dln}(\mathrm{tfp})$ \\
\hline \multirow[t]{2}{*}{$\mathrm{y}_{\mathrm{t}-1}$} & -0.045 & -0.284 & -0.026 & -0.181 & -0.648 \\
\hline & $(0.013)^{* *}$ & $(0.036)^{* *}$ & $(0.010)^{* *}$ & $(0.029)^{* *}$ & $(0.060)^{* *}$ \\
\hline \multirow{2}{*}{$\mathrm{FT}_{\mathrm{i}}$} & 0.473 & 1.362 & 0.353 & 0.518 & 0.502 \\
\hline & $(0.862)$ & (1.097) & $(0.868)$ & $(1.125)$ & $(0.790)$ \\
\hline \multirow[t]{2}{*}{$\mathrm{FE}_{\mathrm{ij}}$} & 0.651 & 3.091 & 0.510 & 2.335 & 0.591 \\
\hline & $(0.252)^{* *}$ & $(0.694) * *$ & $(0.247)^{*}$ & $(0.688)^{* *}$ & $(0.207)^{* *}$ \\
\hline \multirow[t]{2}{*}{$\mathrm{FE}_{\text {is }}$} & -0.125 & -0.473 & -0.171 & -0.783 & -0.644 \\
\hline & $(0.162)$ & $(0.390)$ & $(0.162)$ & $(0.417)+$ & $(0.157)^{* *}$ \\
\hline \multirow{2}{*}{$\mathrm{FT}_{\mathrm{i}} * \mathrm{~s}_{\mathrm{i}}$} & -0.048 & -0.137 & -0.037 & -0.058 & -0.044 \\
\hline & $(0.083)$ & $(0.088)$ & $(0.083)$ & $(0.090)$ & $(0.075)$ \\
\hline \multirow{2}{*}{$\mathrm{FE}_{\mathrm{ij}} * \mathrm{~s}_{\mathrm{i}}$} & -0.060 & -0.302 & -0.046 & -0.224 & -0.056 \\
\hline & $(0.027)^{*}$ & $(0.079)^{* *}$ & $(0.026)+$ & $(0.079)^{* *}$ & $(0.023)^{*}$ \\
\hline \multirow[t]{2}{*}{$\mathrm{FE}_{\mathrm{is}} * \mathrm{~s}_{\mathrm{i}}$} & 0.019 & -0.023 & 0.023 & 0.008 & 0.029 \\
\hline & $(0.017)$ & $(0.039)$ & $(0.017)$ & $(0.041)$ & $(0.014)^{*}$ \\
\hline \multirow[t]{2}{*}{$\mathrm{s}_{\mathrm{i}}$} & 0.004 & 0.032 & 0.003 & 0.027 & 0.006 \\
\hline & $(0.004)$ & $(0.010)^{* *}$ & $(0.004)$ & $(0.010)^{* *}$ & $(0.004)$ \\
\hline \multirow{2}{*}{$\mathrm{E}_{\mathrm{ij}}$} & -0.035 & -0.100 & -0.031 & -0.095 & -0.041 \\
\hline & $(0.044)$ & $(0.128)$ & $(0.044)$ & $(0.132)$ & $(0.037)$ \\
\hline \multirow[t]{2}{*}{$\mathrm{d} \ln (\mathrm{k} / \mathrm{l})$} & -0.009 & 0.153 & & & \\
\hline & $(0.028)$ & $(0.051)^{* *}$ & & & \\
\hline \multirow[t]{2}{*}{$\operatorname{dln}(m / 1)$} & 0.751 & & & & \\
\hline & $(0.025)^{* *}$ & & & & \\
\hline \multirow[t]{2}{*}{$\operatorname{dln}(1)$} & -0.123 & -0.361 & 0.111 & 0.362 & \\
\hline & $(0.058)^{*}$ & $(0.159)^{*}$ & $(0.045)^{*}$ & $(0.155)^{*}$ & \\
\hline \multirow[t]{2}{*}{$\mathrm{d} \ln (\mathrm{k})$} & & & -0.009 & 0.161 & \\
\hline & & & $(0.028)$ & $(0.054)^{* *}$ & \\
\hline \multirow[t]{2}{*}{$\mathrm{d} \ln (\mathrm{m})$} & & & 0.757 & & \\
\hline & & & $(0.025)^{* *}$ & & \\
\hline $\ln (1)$ & & & & & -0.015 \\
\hline \multirow{2}{*}{ Constant } & 0.424 & 1.854 & 0.332 & 1.957 & $\begin{array}{l}(0.015) \\
-0.009\end{array}$ \\
\hline & $(0.153)^{* *}$ & $(0.457)^{* *}$ & $(0.152)^{*}$ & $(0.510)^{* *}$ & $(0.080)$ \\
\hline Observations & 569 & 574 & 569 & 574 & 569 \\
\hline R-squared & 0.89 & 0.32 & 0.89 & 0.29 & 0.42 \\
\hline
\end{tabular}

Robust standard errors in parentheses

+ statistically significant at $10 \%$; $*$ significant at $5 \%$; ** significant at $1 \%$

Regressions include sectoral and time dummies 
Table 4:

Alternative regression results for firms established by owner or family

\begin{tabular}{|c|c|c|c|c|c|}
\hline & (1) & $(2)$ & (3) & $(4)$ & $(5)$ \\
\hline & $d \ln (q / 1)$ & $\mathrm{d} \ln (\mathrm{vad} / \mathrm{l})$ & $d \ln (q)$ & $\mathrm{d} \ln (\mathrm{vad})$ & $\mathrm{d} \ln (\mathrm{tfp})$ \\
\hline \multirow{2}{*}{$\mathrm{y}_{\mathrm{t}-1}$} & -0.042 & -0.271 & -0.026 & -0.175 & -0.650 \\
\hline & $(0.013)^{* *}$ & $(0.035)^{* *}$ & $(0.010)^{* *}$ & $(0.028)^{* *}$ & $(0.061)^{* *}$ \\
\hline \multirow{2}{*}{$\mathrm{FT}_{\mathrm{i}}$} & 0.468 & 1.275 & 0.351 & 0.463 & 0.411 \\
\hline & $(0.850)$ & (1.092) & $(0.855)$ & (1.119) & $(0.792)$ \\
\hline \multirow{2}{*}{$\mathrm{FE}_{\mathrm{ij}}$} & 0.611 & 3.004 & 0.493 & 2.291 & 0.623 \\
\hline & $(0.254)^{*}$ & $(0.690)^{* *}$ & $(0.251)+$ & $(0.683)^{* *}$ & $(0.207)^{* *}$ \\
\hline \multirow[t]{2}{*}{$\mathrm{FE}_{\text {is }}$} & -0.099 & -0.450 & -0.140 & -0.711 & -0.566 \\
\hline & $(0.140)$ & $(0.384)$ & $(0.142)$ & $(0.410)+$ & $(0.159)^{* *}$ \\
\hline \multirow[t]{2}{*}{$\mathrm{FT}_{\mathrm{i}} * \mathrm{~s}_{\mathrm{i}}$} & -0.048 & -0.128 & -0.037 & -0.053 & -0.036 \\
\hline & $(0.081)$ & $(0.087)$ & $(0.082)$ & $(0.089)$ & $(0.076)$ \\
\hline \multirow[t]{2}{*}{$\mathrm{FE}_{\mathrm{ij}} * \mathrm{~s}_{\mathrm{i}}$} & -0.056 & -0.294 & -0.044 & -0.221 & -0.059 \\
\hline & $(0.026)^{*}$ & $(0.078)^{* *}$ & $(0.026)+$ & $(0.077)^{* *}$ & $(0.023) * *$ \\
\hline \multirow[t]{2}{*}{$\mathrm{FE}_{\mathrm{is}} * \mathrm{~s}_{\mathrm{i}}$} & 0.020 & -0.014 & 0.024 & 0.013 & 0.024 \\
\hline & $(0.015)$ & $(0.038)$ & $(0.016)$ & $(0.041)$ & $(0.015)$ \\
\hline \multirow[t]{2}{*}{$\mathrm{S}_{\mathrm{i}}$} & 0.005 & 0.034 & 0.004 & 0.029 & 0.007 \\
\hline & $(0.004)$ & $(0.011)^{* *}$ & $(0.004)$ & $(0.010)^{* *}$ & $(0.004)+$ \\
\hline \multirow[t]{2}{*}{$E_{i j}$} & -0.022 & -0.067 & -0.019 & -0.058 & -0.015 \\
\hline & $(0.042)$ & $(0.129)$ & $(0.042)$ & $(0.132)$ & $(0.035)$ \\
\hline \multirow[t]{2}{*}{$\mathrm{d} \ln (\mathrm{k} / \mathrm{l})$} & -0.012 & 0.139 & & & \\
\hline & $(0.028)$ & $(0.051)^{* *}$ & & & \\
\hline \multirow[t]{2}{*}{$\mathrm{d} \ln (\mathrm{m} / \mathrm{l})$} & 0.745 & & & & \\
\hline & $(0.025)^{* *}$ & & & & \\
\hline \multirow[t]{2}{*}{$d \ln (1)$} & -0.157 & -0.441 & 0.088 & 0.297 & \\
\hline & $(0.053)^{* *}$ & $(0.148)^{* *}$ & $(0.041)^{*}$ & $(0.146)^{*}$ & \\
\hline \multirow[t]{2}{*}{$\mathrm{d} \ln (\mathrm{k})$} & & & -0.012 & 0.147 & \\
\hline & & & $(0.028)$ & $(0.053)^{* *}$ & \\
\hline \multirow[t]{2}{*}{$\mathrm{d} \ln (\mathrm{m})$} & & & 0.750 & & \\
\hline & & & $(0.025)^{* *}$ & & \\
\hline \multirow[t]{2}{*}{$\ln (1)$} & & & & & -0.026 \\
\hline & & & & & $(0.015)+$ \\
\hline \multirow[t]{2}{*}{ Constant } & 0.469 & 2.177 & 0.421 & 2.066 & 0.017 \\
\hline & $(0.186)^{*}$ & $(0.498)^{* *}$ & $(0.184)^{*}$ & $(0.534)^{* *}$ & $(0.162)$ \\
\hline Observations & 550 & 554 & 550 & 554 & 550 \\
\hline R-squared & 0.89 & 0.33 & 0.89 & 0.29 & 0.42 \\
\hline
\end{tabular}

